\title{
Metaphors for Learning Mathematics: An Interpretation Based on Learners' Responses to an Exploratory Questionnaire on Mathematics and Learning
}

\author{
Oniccah Thibodi \\ Department of Mathematics, Science \& Technology Education, Tshwane University of Technology, Pretoria, South Africa
}

Email address:

othibodi@yahoo.com

To cite this article:

Oniccah Thibodi. Metaphors for Learning Mathematics: An Interpretation Based on Learners' Responses to an Exploratory Questionnaire on Mathematics and Learning. International Journal of Secondary Education. Vol. 5, No. 6, 2017, pp. 70-74.

doi: 10.11648/j.ijsedu.20170506.11

Received: October 5, 2017; Accepted: November 13, 2017; Published: January 25, 2018

\begin{abstract}
This paper is linked to some work that I have done in my PhD research, which is in progress. It shows metaphors that learners have about mathematics. These metaphors were investigated through a questionnaire with seven open-ended questionnaires. An inductive analysis of the learners' metaphors for mathematics indicated that learners had well developed and complex metaphors about mathematics, mathematics learning, mathematics teaching and the mathematics teacher. Some mental images were formed: Firstly, the notion that mathematics learning is challenging and may involve anxiety; secondly, that perseverance is needed as continuing effort will bring reward; and lastly, that positive or negative mental images of mathematics are related to the perception of and the active versus passive role of the learner. Considering that the metaphors were collected from learners with an extensive engagement with mathematics learning, the endings would imply that these metaphors reflects the students' mental images formed as a result of experiencing mathematics learning through the use of metaphors.
\end{abstract}

Keywords: Metaphor, Conceptual Metaphor, Learning Mathematics, Teaching Mathematics, Mathematics Teachers

\section{Introduction}

By far the most common reason people give for disliking mathematics is that it has no meaning for them. The challenge for the teacher of mathematics is to find a way or ways in which to make mathematics meaningful for children who find it incomprehensible. One particularly promising way to do this is to find way(s) in which people can think about mathematical concepts in terms of things they already understand, that is to find metaphors. In this study, the use of metaphors is being considered as a cornerstone for meaningful mathematics learning.

Mathematics education students can have a variety of views about the nature of mathematics and about their role in the learning of mathematics. These views are linked to interpretations of the role that mathematics plays in their own lives, both within and outside the school (Cameron, 2003). A study of learners' metaphors of mathematics would provide a means of accessing the beliefs that learners have about mathematics. Identifying and understanding learners' metaphors for mathematics would provide mathematics teacher with insights into learners' internalized mental images about mathematics. Such understandings could inform how beliefs can influence learners' learning and understanding of mathematics (Leder, Pehkonen \& Tomer, 2002). Therefore, the purpose of this study is to explore learners' mental images of mathematics through the use of metaphor.

\section{Background of the Study}

Teaching and learning mathematics in South Africa continues to be challenging at all levels. Some of the challenges originate from the way both teachers and learners perceive the teaching and learning of mathematics. Consequently, in many curricula across the globe, many 
attempts are being made to develop strategies intended at enabling learners learn and gain access to mathematics. Many of the strategies proposed in such generally reformdriven curricula do little to change the nature of mathematics. This is perhaps due to the fact that the discipline of mathematics itself is inherently abstract. Therefore, rather than change the nature of the subject, teaching makes attempts at "softening" (un-hardening!) ways of understanding it. In this paper, the focus is on providing a way of making it more possible to think about mathematics and consequently, learning mathematics. One strategy for making it more possible to think about mathematics is the use of metaphor, expressing one thing in terms of something else (Johnson, 1987).

The central idea behind the use of metaphor is to understand and experience one kind of a thing in relation to another kind (Lakoff \& Johnson, 2005). Metaphors are an allegoric structure formed by establishing a relation between the object through comparing similarities and differences and transferring the experience of one to the other (Palmquit, 2001). Metaphors are regarded as a means that learners can use to express how they see abstract mathematical concepts using different analogies (Cerit, 2008). This possibility is based on the fact that it is possible to improve the emotions, thoughts and skills of the individual with the help of metaphors (Lakoff \&Johnson, 2005)

\section{Statement of the Problem}

Worldwide, policy makers are placing increasing demands on schools and their teachers to use effective and research-informed practices in the teaching of mathematics. The main reason for choosing mathematics is that it is a very abstract subject to learn and understand (McColm, 2007). It is believed that mathematics is a very difficult subject to learn (Parzysz et al., 2005) hence poor results. Mathematics, as it is widely understood, plays a key role in shaping how individuals deal with the various spheres of private, social, and civil life (Anthony \& Walshaw, 2009). Yet today, as in the past, many students struggle with mathematics and become disaffected as they continually confront obstacles to engagement. Therefore, with metaphors, it may be possible to try to comprehend the mental images that students have about the subject that is believed to be difficult and abstract.

\section{Research Questions}

The main questions for the research are:-

1. What metaphorical images do learners use to describe a mathematics teacher, mathematics teaching and learning, and mathematics?

2. What images can be derived from learners' metaphors about a mathematics teacher, mathematics teaching and learning; and mathematics?

\section{Significance of the Study}

In South Africa, parents, students, teachers, employers, professional mathematicians, tertiary institutions and cultural and political organizations are concerned about poor mathematics and science results. The two subject impact negatively towards the country's performance compared to other countries as well as our neighbouring country, Botswana. Reys and Lappan (2007) assert that because mathematics is a foundation discipline for other disciplines and grows in direct proportion to its utility, the curriculum should provide opportunities for all students to develop an understanding of mathematical models, structures and stimulations applicable to many disciplines. Therefore, my study would like to make an important contribution towards improvement in these subjects.

In this way, it will provide useful information that can be used to make recommendations to Policy makers \& curriculum developers in our Country for formulating educational policies that will impact positively towards improving the results of mathematics, as well as improved country's results of matriculates.

Learners are going use the metaphor to express how they see an object using different analogies (Cerit, 2008). They are going to build relations between their former (prior knowledge) and current knowledge by revealing similarities, thus helping to express the new mathematical information in concrete terms (Senemoglu, 2007). They will then form individual concepts that are embedded in mental images.

\section{Conceptual Framework}

The conceptual frame work of this chapter is outlined in the Figure below.

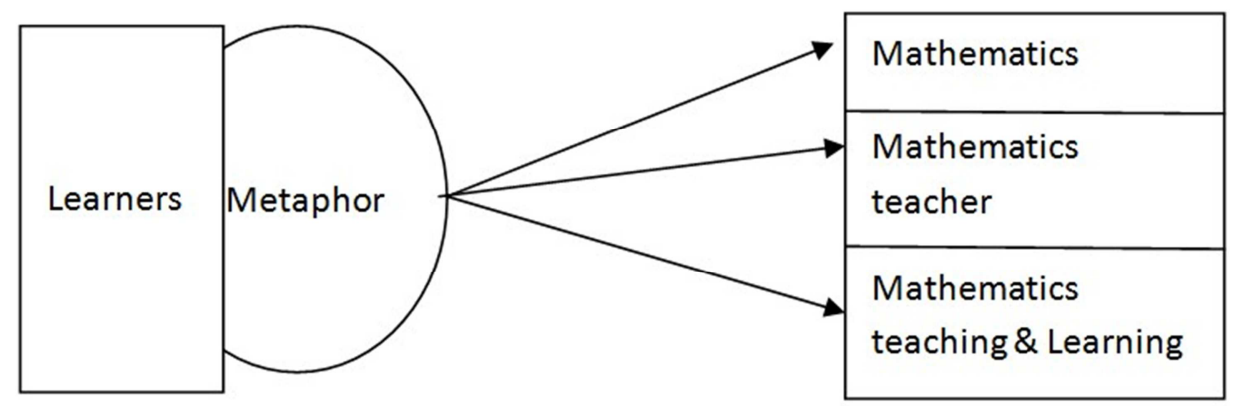

Figure 1. Learners using Metaphor as a lens, screen, or a filter to view target domain. 
The learners' metaphorical expressions of mathematics, mathematics teachers mathematics teaching and learning, depend on their experience with the same. Metaphors on the other side are seen as an attempt to communicate the mental images formed through learners' experience mathematics and form individual concepts that are embedded in mental images. For example, "Mathematics is a Key" or Mathematics teacher is like a Doctor" In this regard "Mathematics and Mathematics teacher" are metaphor topic and "Key and Doctor" are metaphor vehicle. The metaphor topic (target domain) is the subject of a figurative statement and the metaphor vehicle (source domain) is the concept that I used to say something new about the metaphor topic (e.g Mathematics/Mathematics teacher/Mathematics teaching and learning). Saban (2009) suggests that the metaphor vehicle (source domain) provide properties that can be attributed to the metaphor topic (target domain). Therefore, metaphors are seen as an attempt to communicate the mental images formed through learners interacting with target domains.

\section{Research Design, Methodology and Data Collection}

Using a combination of qualitative and quantitative data will improve an evaluation by ensuring that the limitations of one type of data are balanced by the strengths of another. This will ensure that understanding is improved by integrating different ways of knowing. Most evaluations collect both quantitative data (numbers) and qualitative data (text, images). The study requires both the quantitative and qualitative information to interpret my research problem, analyze findings and present them. The qualitative approach may reveal multiple perspectives held by learners (Leedy \& Ormrod, 2005) on their written work. Secondly the study Attempts to describe and interpret (Leedy \& Ormrod, 2005; Opie 2010) of learners understanding and thinking about mathematics and mathematics teachers

The researcher has chosen the nearby school including her school where she is teaching because learners will be easily accessible to her to collect data. The findings can be generalized to learners of other schools within the District of Bojanala, where the study took place.

\section{The Study Population and Research Instruments}

\subsection{Study Population}

The study population was only one class of Grade 10 learners (17: 9 Females and 8 Males) and (27; 19 Male and 8 Female) Grade 11 learners of Boitekong Secondary school. This Secondary school is one of the Public schools we have in Rustenburg. The total number of secondary school learners was 44.

Another population comes from Grade 4 learners $(166,89$ girls and 77 boys) of 5 primary schools of one of the public schools in Rustenburg. The Grade 6 learners of one school were (146) three classes. The total number of Intermediate learners was 312 .

\subsection{The Research Instruments}

The research instruments were structured in English because the respondents use English as Language of Learning and Teaching (LoLT). The instruments were based on metaphors that were used by teachers and learners in the teaching and learning of mathematics. It was developed by the researcher with the assistance of supervision from her supervisor. The instruments used by learners were the questionnaire comprising of two parts. Part A: Complete the following statements as best as possible, according to your thinking and Part B: Yes/No/Not sure type of statements.

\section{Data Analysis and Results}

The findings indicate that the learners had complex but well-developed views about mathematics. They used various kinds of metaphors in their descriptions of the mathematics, mathematics learning, mathematics teaching and mathematics teachers. They were constantly grappling with powerful metaphors to express their mental images, some of which were edifying and others were debilitating.

Some of the summary of learners' responses will be shown on table 1 and table 2 below. In the exploratory study, the researcher intended to document learners' responses to questionnaire items such as indicated in the following table (with an example shown in the second row). These are a few:

Table 1. Responses to questionnaire items.

\begin{tabular}{lll}
\hline If mathematics is like a....... & then learning mathematics is like... & Reason \\
\hline $\begin{array}{l}\text { house } \\
\text { taxi }\end{array}$ & entering a house & Any house has rules \\
& Driving a taxi & Addition and subtraction operations are practiced daily \\
supermarket & Running a supermarket & All mathematical operations including shapes are found in the supermarket. \\
knife & Using a sharp knife to cut meat & You are also a manager \\
shoes & Wearing a new pair of shoes & Knives are used for correct measurement \\
map & Drawing a map of your journey & New shoes are more comfortable and you feel the pride \\
$\begin{array}{l}\text { lunch bar } \\
\text { novel }\end{array}$ & Enjoying a lunch bar & You need to follow certain routes to arrive at your final destination \\
door & Reading a novel & Enjoy doing the mathematical expressions \\
\hline
\end{tabular}




\begin{tabular}{lll}
\hline If mathematics is like a...... & then learning mathematics is like... & Reason \\
\hline cat & A cat hunting its prey & You learn better in a more conducive environment \\
flower & Nurturing the flower & The more you nurture the flower the more beautiful it becomes \\
chess & Playing a chess & Chess is a game most learners enjoy. \\
ice-cream & Enjoying the ice-cream & Ice-cream is more enjoyable in summer when it is very hot. Timing is very \\
mirror & You mirror yourself against others & important in mathematics \\
river & Crossing a river & You yourself \\
movie & Watching a movie at cinema & You relax when you are watching a movie \\
gate & Locking a gate & No one can open the locked mind of a learner except a teacher \\
big rock & Climbing a big rock & It's not easy to climb a big rock. It needs time to prepare for that. Mindset \\
lion & You are a giant & Mathematics learners cannot be defeated. \\
\hline
\end{tabular}

The aspects in column one were aspects associated with physical structures/containers (e.g. house), animals (e.g. lion), power, journey, comfort, abused substances, aspects linked to enjoyment, things to read, those linked to light, things one can wear, and edibles.

The other type of open ended questionnaire given to learners. The researcher took some of the questionnaire and some of their responses

Table 2. Yes/No/Not sure responses.

\begin{tabular}{|c|c|c|c|}
\hline statements & Yes. reason & No. reason & Not sure. reason \\
\hline $\begin{array}{l}\text { A mathematics teacher is } \\
\text { like an English teacher }\end{array}$ & $\begin{array}{l}\text { - He teaches mathematics in English } \\
\text { - Maths is taught in English }\end{array}$ & $\begin{array}{l}\text { - maths cannot be compared to } \\
\text { English } \\
\text { - he makes mathematics more } \\
\text { enjoyable like you live it in daily } \\
\text { bases }\end{array}$ & $\begin{array}{l}\text { - he is more active and funny than } \\
\text { an English teacher }\end{array}$ \\
\hline $\begin{array}{l}\text { A mathematics teacher is } \\
\text { like a Doctor }\end{array}$ & $\begin{array}{l}\text {-Because he advices learners to make good } \\
\text { decisions } \\
\text {-Because he/she is intelligent/smart }\end{array}$ & $\begin{array}{l}\text { - he does not nurse us } \\
\text { - A maths teacher cannot cure leaner } \\
\text { in class }\end{array}$ & $\begin{array}{l}\text { - he is not comforting like a doctor } \\
\text { but he encourages us to the right } \\
\text { thing } \\
\text { - because we can also use } \\
\text { mathematics in doctors work }\end{array}$ \\
\hline $\begin{array}{l}\text { A mathematics teacher is } \\
\text { like a gate }\end{array}$ & $\begin{array}{l}\text { - It open doors to opportunities } \\
\text { - He open our mind \& lead us to the future }\end{array}$ & $\begin{array}{l}\text { - Yes because when he teaches us he } \\
\text { opens new things for us like giving } \\
\text { new formulas for calculations } \\
\text { - You control a gate but mathematics } \\
\text { teacher teach you }\end{array}$ & No. I don't understand \\
\hline $\begin{array}{l}\text { When in a mathematics } \\
\text { class, I feel like I am in a } \\
\text { taxi? }\end{array}$ & $\begin{array}{l}\text { - Because I always listen attentively in } \\
\text { class } \\
\text {-Because mathematics is my ride to } \\
\text { success/ who I want to be }\end{array}$ & $\begin{array}{l}\text { - because the teacher has a voice that } \\
\text { makes you love education } \\
\text {-because in a taxi there is no order }\end{array}$ & $\begin{array}{l}\text { - when in maths class I feel free and } \\
\text { my mind it is concentrating on what } \\
\text { the teacher is saying } \\
\text { - the taxi is very noisy }\end{array}$ \\
\hline $\begin{array}{l}\text { A mathematics teacher is } \\
\text { like any other teacher at } \\
\text { school }\end{array}$ & $\begin{array}{l}\text { - He has more potential than any other } \\
\text { teacher } \\
\text { - They all teach, but different subjects }\end{array}$ & $\begin{array}{l}\text {-Mathematics teacher is always active } \\
\text { than other teachers } \\
\text { - He is different from all the teachers } \\
\text { god[got] good style of teaching }\end{array}$ & $\begin{array}{l}\text {-He might be human but I am not } \\
\text { sure his like the others }\end{array}$ \\
\hline
\end{tabular}

In response to statement one, most respondents (Learners) had a specific teacher in mind. They used "he" that conclude to say their mathematics teacher is a man. Most often they compare that man with their English teacher and came up with solutions that makes them to feel they are not like each other. The second statement that compares mathematics teacher with a doctor, they said: "Because he advices learners to make good decisions" and "Because he/she is intelligent/smart". The two statements match each other most so that we expect the adviser to be more knowledgeable on the things they give advice on. The not sure response indirectly support the first statement when it says " ...... but he encourages us to the right thing" More responses were supporting the statements. In summary of the above table, the statements were comparing mathematics teacher with English teacher, Doctor, gate, any other teacher. All except English teacher, the responses were supporting the given statements with various reasons.

\section{Conclusion}

The study in progress, identified the metaphors that mathematics learners used to describe their experiences with mathematics learning and explored the source of these metaphors. Some of the learners who participated in this study provided a wide range of metaphors which reflected the positives and negative mental images about mathematics. General metaphors about mathematics indicated that learners' find mathematics quite challenging but possible to learn if one is determined to understand it. Learners perceived that learning mathematics is a never-ending struggle, for example, like driving on bumpy road. Teaching mathematics is like caring for a baby; one has to proceed with care and confidence. From experience, several respondents described a mathematics teacher in very positive light. Ideally, a mathematics teacher has been likened to a doctor whose job it is to ensure that patients are cured, which 
is acknowledged not to be the case for many learners

The application of metaphors becomes pervasive: learners use metaphors to conceptualize, to represent and to communicate thoughts and actions in their everyday lives. Learners use metaphors in their day-to-day lives to describe mathematics without even knowing it. All theories of mathematics are based on implicit images or metaphors that persuade learners to see, understand and imagine mathematics sometimes in particular ways. Thus, metaphors becomes vital to understanding and highlighting certain aspects of mathematics to learners (Parzysz, Pesci \& Bergsten, 2005), because they create insight.

\section{References}

[1] Association for Mathematics Education of South Africa. (2009). Report on the evaluation of Questions in Mathematics. Senior Phase. November 2009, AMESA. South Africa.

[2] Cameron, L. (2003). Metaphor in educational discourse. London: Continuum.

[3] Department of Basic Education. (2011). Curriculum and Assessment policy statement grades $10-12$. Mathematics. Pretoria. Department of Basic Education.

[4] Epstein, A. S. (2007). The intentional teacher. Choosing the best strategies for young children's learning. Washington, DC: National Association for the Education of Young Children.

[5] Johnson, M. (1987). The body in the mind: The bodily basis of meaning, imagination, and reason. Chicago: Chicago University Press.

[6] Kilic, C. (2010). Belgian and Turkish pre-service primary school mathematics teachers' metaphorical thinking about mathematics. Proceedings of CERME 7, Rzeszow, Poland.
[7] Lakoff, G. \& Johnson, M. (2005). Metaphor we live by, Chicago, Illinois: University of Chicago Press.

[8] Leavy, A. M., Mc Sorley, F. A., \& Bote, L, A. (2007). An examination of what metaphor construction reveals about the evolution of preservice teachers' beliefs about teaching and learning. Teaching and Teacher Education, 23, 1217-1233.

[9] Leder, G., Pehkonen, E., \& Torner, G. (2002). Beliefs: A hidden variable in mathematics education? Dordrecht: Kluwer Academic.

[10] Leedy P. D \& Ormrod J. E. (2005). Practical Research. Planning and Design $\left(8^{\text {th }}\right.$ Edition. Person Education International. Upper Saddle River. New Jersey.

[11] McColm, G. (2007). A metaphor for mathematics education. Notices of the AMS, 54(4), 499-502.

[12] Opie, C. (2010). Doing education research. SAGE Publication. Wiltshire. Chapter 6, pp 95-129.

[13] Palmquite, R. A., (2001). Cognitive style and users' metaphors for the web: Exploratory study. Journal of Academic Librarianship 27 pp 24-35.

[14] Parzysz, B., Pesci, A., \& Bergsten, C. (2005). The role of metaphors and images in the learning and understanding of mathematics. Fourth Congress of the European Society of Research in Mathematics Education (pp. 67-70).

[15] Saban A. (2009). Functions of Metaphors in Teaching and Teacher Education. A Review Essay. Teacher Education. 17(4): 299-315.

[16] Saban, A., Kocbeker, B. N., \& Saban, A. (2007). Prospective teachers' conceptions of teaching and learning revealed through metaphor analysis. Learning and Instruction, 17, 123139.

[17] Sfard, A. (1998). Two metaphors for learning and the dangers of choosing just one. Educational Researcher, 27(2): 4-13. 